\title{
Lietuvos „kova“ su korupcija: kodèl nepastebime pažangos?
}

\begin{abstract}
Straipsnio tikslas - aptarti ir išanalizuoti pastangas mažinti korupciją Lietuvoje socialinio konstrukcionizmo tradicijos rèmuose. Straipsnyje nagrinejami Europos Sąungos antikorupciniai interesai, aptariamas korupcijos problemos iškilimas Lietuvoje, korupcijos objektyvacijos elementai ir antikorupcinès praktikos Lietuvoje. Teigiama, kad Lietuvos pastangos mažinti korupciją jau igavo antikorupcinès "pramonès" pavidalą. Straipsnio pabaigoje konstatuojama, kad antikorupcinès pramonès apraiškos padidina korupcijos matomumą Lietuvos visuomeneje; tarptautiniai korupcijos tyrimai Lietuvoje yra nepelnytai sureikšminami ir jų pagrindu apibūdinama „tikrovë“ ir kuriamos antikorupcinès iniciatyvos neatsižvelgiant ị nacionalinius ypatumus; antikorupcinių iniciatyvų veiksmingumo ịvertinimas reikalauja daugiau laiko; negatyvi informacija apie pastangas mažinti korupciją stipriai užgožia pozityvią. Visi paminèti veiksniai sąlygoja tai, kad pažanga korupcijos mažinimo srityje dažnai lieka nepastebèta Lietuvoje.
\end{abstract}

\section{Ivadas}

Pasaulyje aktyviai su korupcija „kovojama ${ }^{1 “}$ jau beveik tris dešimtmečius, Lietuvoje kiek trumpiau, tačiau rezultatai, ypač kurie yra pabrěžiami viešoje erdvèje, panašūs - korupcijos problema nemažeja ir kelia vis naujas tarptautines ir nacionalines grèsmes. Šioje „kovoje“ dalyvauja skirtingus interesus turintys veikejjai su vis naujomis priemonėmis: šalių vyriausybės griežtina bausmes ir ịpareigoja antikorupcines agentūras aktyviau „kovoti“ su šiuo reiškiniu, Europos Sąjunga (ES) griežtina „kovos“ su korupcija pastangų stebejimą, Pasaulio bankas ketina pasitelkti naujausias technologijas, tarptautinè

\footnotetext{
* Dr. Jolanta Aleknevičiene - Generolo Jono Žemaičio Lietuvos karo akademijos Strateginių tyrimų centro vyresnioji mokslo darbuotoja. Adresas korespondencijai: Šilo 5a., LT-10322 Vilnius, tel. (8 5) 2103571, el. p. jolanta.alekneviciene@gmail.com

${ }^{1}$ Žodis „kova“ korupcijos problematikos kontekste ar žodžių junginys „,kova su korupcija“ pakankamai dažnai vartojamas ịvairiose Lietuvos, neretai ir ES, teisiniuose, dokumentuose, programose ir t. t. Straipsnio autorès manymu, žodžio „kova“ naudojimas korupcijos kontekste, tik pabrěžia griežtą toną, bet nenusako veiklos turinio, todèl „,kova su korupcija“ ar tiesiog „kova“ straipsnyje rašoma kabutėse ir suprantama kaip metafora antikorupcinei veiklai apibūdinti. Kadangi konstrukcionizmo tradicijos rèmuose apibrèžčių formulavimas ir taikymas yra svarbus analizės aspektas, straipsnyje žodis „kova“ ar žodžio junginys „kova su korupcija“ išlieka.
} 
skaidrumo organizacija Transparency International - kiekvieną visuomenès narị, Tarptautinè antikorupcijos akademija - mokslą.

$2012 \mathrm{~m}$. Lietuvos 15-osios Vyriausybès vadovas dalyvaudamas Tarptautinès antikorupcijos dienos minèjime teigè, kad „kovą su korupcija turètume pradèti nuo šeimos ir mokyklos “2. Tais pačiais metais Lietuvos moksleivių sąjunga kartu su LR Specialiųjų tyrimų tarnyba (STT) kvietė moksleivius dalyvauti eilèraščių konkurse „Lietuva be korupcijos“. Taigi, tiek tarptautinis, tiek nacionalinis viešasis diskursas byloja, kad šioje „kovoje“ dalyvauja kone visi ivvairiausiomis priemonemis. Tačiau kodèl korupcijos grèsmè nemažèja ir mes nepastebime korupcijos mažèjimo Lietuvoje?

Šių klausimų analizei yra reikalingas kritinis požiūris ì korupcijos reiškinị. Prieš pradedant apie ji kalbèti plačiau, verta paminèti, kad tradiciniai korupcijos fenomeno interpretacijos ir analizès požiūriai (moralès, funkcionalistinis ir politinès ekonomijos) ir jų pagrindu kuriami ir taikomi šios problemos sprendimo būdai yra nepakankami. Šiame straipsnyje bus pasitelkiamas kritinis požiūris ị korupciją. Jo kontekste taikoma socialinio konstukcionizmo tradicija $^{3}$ atskleidžia rečiau akcentuojamus ar net naujus šio reiškinio aspektus. Pažymètina, kad fragmentiškai kritinị požiūrị korupcijos fenomeno studijose taikè Frankas Anechiarico, Peteris Bratsis, Alanas Doigas, Aleksandras Dobryninas, Angelos Giannakopoulos, Markas Granovetteris, Jamesas B. Jacobsas, Christopheris Kayes, Stenhenas Kotkinas, Ivanas Krastevas, Konstadinosas Marasas, Heather Marquette, Bryanas Michaelis, Quentinas Reedas, Andras Sajo, Dirkas Tanzleris ir kt.

Socialinio konstrukcionizmo tradicija, kurios kontekste visuomenès ir atskirų individų suvokiama tikrovė yra jų ir grupių socialinės sąveikos reiškinys, praplečia socialinių problemų, tarp jų ir korupcijos, nagrinejjimo ir aiškinimo galimybes. Šios tradicijos rèmuose ypatingas dėmesys yra skiriamas grupẻms ar institucijoms, turinčioms galią visuomeneje, t. y. tiems, kurie gali daryti įtaką žmonių nuomonei ir socialinių problemų koncepcijoms. Straipsnyje naudojamas teorinis modelis apima žinojimo sociologijos ir kritinès kriminologijos teorines perspektyvas ${ }^{4}$. Pritaikius kritinio kriminologo Richardo Quin-

2 LR Vyriausybè, Premjeras: kova su korupcija turètume pradèti nuo šeimos ir mokyklos, http://www.lrv. lt/lt/naujienos/aktualijos/?nid=11498, 20121121.

3 Pažymètina, kad kai kurie autoriai pabrèžia socialinio konstrukcionizmo ir socialinio konstruktyvizmo perskyrą. Straipsnio autore pritaria George Hruby, kuris prašo nepainioti šių sąvokų ir teigia, kad socialinis konstrukcionizmas siejamas su sociologiniu žinojimo aprašymu, o socialinis konstruktyvizmas - su psichologiniu. Hruby G., ,Sociological, postmodern, and new realism perspectives in social constructionism: Implications for literacy research“, Reading Research Quarterly, 36, 2001, p. 48-62.

${ }^{4}$ Šis teorinis modelis plačiai aprašytas ir pristatytas straipsnio autorès daktaro disertacijoje Piliponytė J., „Korupcijos konstravimas: pokomunistinių šalių praktika“, Vilnius, 2006. 
ney ir žinojimo sociologijos atstovų Peterio L. Bergerio ir Thomo Luckmanno pasiūlytus tyrimo teorinius instrumentus yra praplečiamos korupcijos fenomeno analizès ir aiškinimo galimybès.

Bergeris ir Luckmannas išplètojo fenomenologinès sociologijos principą - tikrovè yra socialiai konstruojama. Socialinio tikrovès konstravimo pagrindas yra institucionalizacija. Bergeris ir Luckmannas kalba apie tikrovę ne materialiąja objektyviąja prasme, bet kaip apie tam tikrų žinių apie socialinị pasaulį visumą. Patys autoriai iškelia klausimą: „kokiu būdu subjektyvios prasmès tampa objektyviu faktiškumu"? Atsakymo ieškome analizuodami visuomenę kaip objektyvią ir subjektyvią tikrovę ir dialektinius jos procesus. Visuomené, anot autoriu, yra suprantama kaip dialektinis procesas, kurị sudaro trys etapai: eksternalizacijos, objektyvacijos ir internalizacijos.

Quinney socialinès nusikaltimų tikrovès teorija ${ }^{6}$ prasideda nuo prielaidos, kad nusikaltimai nèra sąlygoti savaiminio elgesio prigimties. Nusikaltimas greičiau yra tokia žmogiško elgesio apibrèžtis, kurią politinèje visuomenèje sukuria ir ịtvirtina igalioti politiniai veikèjai (policija, teismai, korekcijos institucijos). Nusikaltimas yra dirbtinis konstruktas, sukurtas galią turinčių visuomenès segmentų, siekiant patenkinti savo interesus. Individai tampa nusikaltèliais, kai kiti jų elgesị apibrèžia kaip nusikalstamą.

Taigi, korupcijos problemos konstravimo traktavimas Bergerio ir Luckmanno siūlomais internalizacijos (korupcijos sąvokos kilmé, korupcijos problemos iškèlimas), objektyvacijos (kai intersubjektyvios sąveikos procese ši problema yra „objektyvizuojama“ ir tampa apibrěžčių, diagnostikos instrumentų, tyrimų ataskaitų išraiška) ir eksternalizacijos (kai tokia supanti „kriminalinë” tikrove yra perimama ir tampa praktikos dalimi - antikorupcinèmis strategijomis, programomis, mokymais) aspektais ir Quinney nusikaltimų socialinés tikrovès konstravimo modelio, akcentuojančio institucinę galią ir interesus, taikymas igalina išnagrinèti ir Lietuvos atveji.

Pirmoje straipsnio dalyje nagrinèjami antikorupciniai ES interesai. Antroje dalyje analizuojamas korupcijos problemos iškilimas ir aiškinimas Lietuvoje. Trečioje - aptariama korupcijos objektyvacija: apibrèžtys ir diagnostikos instrumentai, o ketvirtoje - korupcijos eksternalizacija: antikorupcinès praktikos Lietuvoje. Pabaigoje pateikiamos esminès jižvalgos.

\footnotetext{
${ }^{5}$ Berger P., Luckmann T., Socialinès tikrovès konstravimas. Žinojimo sociologijos traktatas, Vilnius: Pradai, 1999, p. 31.

${ }^{6}$ Quinney R., The Social Reality of Crime (Second edition), New Brunswick (U.S.A.) and London (U.K.): Transaction Publishers, 2004.
} 


\section{Lietuva antikorupcinių Europos Sajungos interesų kontekste}

Lietuva kaip ir kitos Vidurio ir Rytų Europos pokomunistinės šalys po komunizmo žlugimo sieke įsilieti į pasaulines ekonomines ir saugumo organizacijas, tokias kaip ES ir Šiaurès Atlanto sutarties organizacija ir vykdè integracijos sąlygas ir reikalavimus. Antikorupcinis kriterijus buvo vienas svarbiausių stojant $\underset{\text { E ES. }}{ }$. „Tarptautinés organizacijos suprato, kad gali susidurti su didelemis problemomis issileidusios šalis, kuriose silpna ịstatymo viršenybe ir plačiai paplitusi korupcija “7 Tarptautinių tarpvalstybinių ir tarptautinių nevyriausybinių organizacijų vaidmuo buvo pagrindinis iškeliant korupcijos problemą į viešumą Vidurio ir Rytų Europos pokomunistinės šalyse, tarp jų ir Lietuvoje. ES palyginti su kitomis tarptautinèmis organizacijomis, tokiomis kaip, Ekonominio bendradarbiavimo ir plètros organizacija, Pasaulio banku, Tarptautiniu valiutos fondu ir Europos Taryba, daugiausia prisidejjo prie korupcijos temos iškèlimo Rytų ir Vidurio Europos pokomunistinèse šalyse ${ }^{8}$. Todèl didžiausias dèmesys ir bus skiriamas Europos Sajungos institucijų antikorupcinèms praktikoms analizuoti.

Pastangos kriminalizuoti korupciją, suteikti jai baudžiamosios justicijos referentus, leidžia pažvelgti ị korupcijos fenomeną Quinney siūlomu konstrukcionistiniu požiūriu9. Todèl analizei atlikti bus taikoma Quinney nusikaltimų socialinès tikrovès konstravimo modelio struktūra. Pagrindinis dèmesys bus skirimas korupcijos fenomeno apibrèžčų formulavimui ir taikymui bei institucijų galios ir interesų nagrinejjimui.

ES pakankamai vèlai pradèjo antikorupcines kampanijas palyginti su kitomis tarptautinemis organizacijomis. Tačiau korupcija, kaip vienas didžiausių ES rūpesčių šalyse kandidatèse, tarp jų ir Lietuvoje, buvo minima visuose Europos Komisijos (toliau - EK) Reguliariuose pranešimuose nuo 1997-ųjų. 2001-ųjų pranešime buvo pabrèžiama, kad korupcija tebelieka rimta problema (jei ne potencialiu barjeru) stojimo į ES atžvilgiu ${ }^{10}$.

\footnotetext{
${ }^{7}$ Holmes L., „,Corruption and the Crisis of the Post-Communist State”, Crime, Law \& Change 27, 1997, p. 287.

${ }^{8}$ Grigorescu A., , The Corruption Eruption in East-Central Europe: The Increased Salience of Corruption and the Role of Intergovernmental Organizations", East European Politics and Societies, Vol. 20., No. 3., 2006, p. 516-549.

${ }^{9}$ Dobrynino A., Žilinskienès L. pranešimas ,Socialinis korupcijos konstravimas: viešojo diskurso atvejis“ skaitytas Nacionalinėje Lietuvos sociologų konferencijoje „Ar gali sociologija pakeisti Lietuvos visuomenę“, 20101126.

${ }^{10}$ European Commission, Making a success of enlargement: Strategy Paper and Report of the European Commission on the progress towards aAccession by each of the candidate countries, http://ec.europa.eu/ enlargement/archives/pdf/key_documents/2001/strategy_en.pdf, 20121120.
} 
ES susirūpinimas korupcijos klausimais buvo žymus, nes korupcija buvo plačiai pripažinta didele problema pokomunistinèse šalyse ${ }^{11}$. Be to, dauguma politologų buvo vieningi, kad korupcija silpnina demokratiją ir turint galvoje, kad korupcija iškreipia rinkas, o ES svarbiausias siekis yra sukurti bendrą rinką, korupcijos klausimas tapo stojimo proceso į ES būtina sąlyga ${ }^{12}$. Taip pat pabrèžiama, kad korupcijos mastai daugelyje šalių gali trukdyti acquis communautaire igyvendinimui ir pakenkti demokratinių institucijų kokybei.

Atviros visuomenès instituto ataskaitoje teigiama, kad EK susirūpinimas dèl korupcijos Lietuvoje buvo labai svarbus plètojant Lietuvos antikorupcinę politiką. EK suteikẻ didelę pagalbą kuriant antikorupcinę politiką, o ypač kuriant Nacionalinę antikorupcinę strategiją ${ }^{13}$. Taigi, Lietuva figūravo ES antikorupcinių interesų lauke. Todèl yra svarbu aptarti ES antikorupcinę praktiką, siekiant suprasti ir paaiškinti Lietuvos korupcijos problemos ir antikorupciniu veiksmų ištakas.

Prieš beveik 20 metų atsirado pirmieji ES antikorupciniai instrumentai ${ }^{14}$ : 1) Konvencija dèl Europos Bendrijų finansinių interesų apsaugos (1995 m.). 2) Konvencijos dèl Europos Bendrijos finansinių interesų apsaugos pirmasis protokolas (1996 m.). 3) Konvencija dèl Kovos su korupcija, susijusia su Europos Bendrijų pareigūnais ar Europos Sąjungos valstybių narių pareigūnais (1997 m.). 4) Konvencijos dèl Europos Bendrijos finansinių interesų apsaugos antrasis protokolas (1997 m.), kuriame pirmą syki paminètos aktyvios ir pasyvios korupcijos sąvokos. 5) Jungtinè Europos Tarybos ir ES programa „OCTOPUS I“ ir „OCTOPUS II“ patarinèjo šalims kandidatems, kokiomis priemonemis kovoti su organizuotais nusikaltimais ir korupcija. 6) $1999 \mathrm{~m}$. buvo įsteigta Europos kovos su sukčiavimu tarnyba (vadinama OLAF trumpiniu), kurios misija - apsaugoti ES interesus, kovoti su sukčiavimu, korupcija ir kita neteisèta veika, įskaitant Europos institucijų neteisètus veiksmus. 7) Pasiektas bendras susitarimas: Europos Taryba, Europos Komisija, Europos Parlamentas, Europos ekonomikos ir socialinių reikalų komitetas parengè bendradarbiavimo pranešimą dèl ES politikos kovojant su korupcija (2003).

Akivaizdu, kad ankstyvieji ES antikorupciniai veiksmai buvo susiję su

\footnotetext{
${ }^{11}$ World Bank, Anticorruption in Transition. A contribution to the policy debate, Washington DC: World Bank, 2000, xv-xviii.

${ }^{12}$ Atviros visuomenès institutas, Stojimo $i$ ES stebésenos procesas: korupcija ir antikorupciné politika, Budapeštas: Atviros visuomenès institutas, 2002 p. 16.

${ }^{13}$ Ibidem, p. 78.

${ }^{14}$ Europos Komisija formuodama antikorupcinę politiką rèmėsi Ekonominio bendradarbiavimo ir plètros organizacijos konvencija dẻl Kovos su užsienio šalių pareigūnų papirkinejjimu tarptautiniuose verslo sandoriuose, Jungtinių Tautų konvencija prieš korupciją, bendradarbiavo su Europos Tarybos sukurta kovojančių su korupcija šalių grupe (GRECO).
} 
finansinių ir politinių interesų užtikrinimu šalyse kandidatėse. Daugiausia dèmesio buvo skiriama baudžiamųjų antikorupcinių ịstatymų kūrimui ir ịgyvendinimui. EK rekomendacijos šalims kandidatèms dažniausiai buvo nukreiptos ¡̇ kontrolès sistemą. Antikorupcinèje praktikoje ES pirmenybę teikè antikorupcinėms taisyklèms ir procedūroms kurti. Didžiausias dėmesys buvo skiriamas kyšininkavimui, o tai nurodo i̇ sąlyginai siaurą korupcijos problemų lauką ir apibrežtt ankstyvuoju laikotarpiu. Taip pat pastebetina, kad korupcijos problema dažniausiai buvo priskiriama tik valstybès sektoriui.

Vèliau (nuo 2004 m.) ES antikorupcinè praktika kiek pakito - korupcija buvo suvokiama platesniame kontekste, ịvesta politinès korupcijos sąvoka, akcentuojama korupcija privačiame sektoriuje, ypatingas dèmesys skiriamas ES lěšu ir paramos skaidrumui, be to, skaidrumas pradètas akcentuoti kaip bendroji vertybè.

Naujausiame ES antikorupciniame etape, praejus daugiau nei 10 metu nuo pradètų antikorupcinių iniciatyvų, EK pažymi, kad korupcija yra vienas iš rimčiausių nusikaltimų tarpvalstybinèje plotmèje ir susijusi su kitais rimtais nusikaltimais, tokiais kaip prekyba narkotikais ir žmonèmis. Todèl 2009 m. Europos Vadovų Taryba, priimdama Stokholmo programą, ${ }^{15}$ suteikè EK politinị igaliojimą išmatuoti kovos su korupcija veiksmingumą ir, bendradarbiaujant su GRECO, suformuoti išsamią ES antikorupcinę politiką. Stokholmo programoje korupcija suprantama ekonominių nusikaltimų kontekste. Akcentuojama korupcijos problema privačiame sektoriuje ir "kova“ su korupcija acquis srityse - viešųjų pirkimų, finansinès kontrolès ir kt.

Stokholmo programos ir kitų susijusių kovos su korupcija dokumentụ $^{16}$ išvadoje, $2011 \mathrm{~m}$. EK paskelbẻ dokumentą apie kovą su korupciją $\mathrm{ES}^{17}$. Tokio dokumento poreikis grindžiamas korupcijos žala visoms ES valstybėms narèms. Kaip prioritetinis akcentuojamas ekonominis interesas: „dèl korupcijos yra patiriama finansinių nuostolių: mažiau investuojama, sutrinka vidaus rinkos veikimas ir mažèja valstybès finansų ${ }^{\text {“18. }}$. Pabréžiama, kad dabartiniai kovos su korupcija stebejjimo ir vertinimo mechanizmai yra nepakankami ir

\footnotetext{
${ }^{15}$ European Council, The Stockholm programme - an open and secure Europe serving and protecting citizens, Official journal of the European Union, 2010/C.

${ }^{16}$ The EU Internal Security Strategy in Action: Five steps towards a more secure Europe, 2010. Written Declaration No 2/2010 of the European Parliament on the Union's efforts in combating corruption, 2010. European Council Resolution 6902/05 on a comprehensive EU policy against corruption, 2005. The European Parliament Resolution on the Commission Communication on a comprehensive EU policy against Corruption4, 2003.

17 European Commission, Fighting Corruption in the EU, http://ec.europa.eu/dgs/home-affairs/news/ intro/docs/110606/308/1_en_act_part1_v121.pdf, 20121102.

${ }^{18}$ Ibidem, p. 3
} 
kad kovos su korupcija teisinè sistema ES valstybėse narèse taikoma nevienodai ir apskritai nepatenkinamai. Todèl ES antikorupcinemis ataskaitomis bus siekiama ${ }^{19}$ suteikti valstybėms narèms papildomą akstiną veiksmingai kovoti su korupcija, visų pirma, priimti ir taikyti tarptautiniu mastu sutartus kovos su korupcija standartus $<\ldots>^{20}$. Komisija ragina ES valstybes nares užtikrinti, kad visos susijusios teisinès priemonès būtų perkeltos ị jų teisę ir, svarbiausia, veiksmingai toliau stebimos ir igyvendinamos <...>. Galiausiai EK pažymi, kad būtina imtis ES masto veiksmų ir visose ES valstybèse narèse stiprinti politini ryžtą kovoti su korupcija ${ }^{21}$.

Taigi, Lietuvos antikorupcinè politika didžia dalimi yra sąlygota ES antikorupcinès praktikos ir atskirų jos antikorupcinių veiksmų. ES antikorupcinè praktika nèra sisteminè, nuosekli ir lyginamoji (lyginimas įmanoma tik tarp šalių kandidačių tam tikru laikotarpiu). ES kompetencija antikorupcijos srityje daugiausia yra sukoncentruota ị ES finansinių interesų apsaugą, o šalys narés (ypač senosios) nèra suinteresuotos, kad EK antikorupcijos srityje igytų daugiau kompetencijos ${ }^{22}$. Konstrukcionistiniu požiūriu, tai kad pastaruoju metu ES siekia „kovos“ su korupcija pastangu ívertinimo visose, ne tik naujose, ES šalyse, iš esmès gali keisti diskusijas apie korupciją tiek Lietuvoje, tiek visoje ES. Šias diskusijas papildytų ir ES primygtinai siūlomų tarptautiniu mastu sutartų kovos su korupcija standartų priemimas ir taikymas visose ES šalyse.

\section{Korupcijos problemos iškilimas}

Lietuvoje „kova“ su korupcija prasidejjo beveik prieš du dešimtmečius: 1993 m. buvo ịsteigtas Kovos su organizuotu nusikalstamumu skyrius, kurio pavadinimas po ménesio buvo pakeistas ị Organizuotų nusikaltimų ir korupcijos tyrimo skyrių, $1996 \mathrm{~m}$. LR Vyriausybė pritarė antikorupcinių priemonių planui ${ }^{23} .1997 \mathrm{~m}$. buvo ịsteigta STT prie LR Vidaus reikalų ministerijos, kurios tikslas buvo sumažinti korupcijos įtaką valstybès gyvenimui. $2000 \mathrm{~m}$.

\footnotetext{
${ }^{19}$ European Commission, Establishing an EU Anti-corruption reporting mechanism for periodic assessment ("EU Anti-corruption Report"), http://ec.europa.eu/dgs/home-affairs/what-we-do/policies/pdf/ com_decision_2011_3673_final_en.pdf, 20121102.

${ }^{20}$ Lietuva dar yra neratifikavusi Ekonominio bendradarbiavimo ir plètros organizacijos kovos su papirkimu konvencijos. EK primygtinai prašo, kad šios konvensijos neratifikavusios valstybės narès nedelsdamos jas ratifikuotų.

${ }^{21}$ European Commission, (note 14).

${ }^{22}$ LR Ministro Pirmininko tarnyba, Korupcijos prevencijos įstatymo poveikio vertinimo galutine ataskaita, 2011, p. 17.

23 Lietuvos Respublikos Vyriausybès nutarimas Nr. 356 ,Dėl priemonių nusikaltimų, susijusių su korupcija, kontrolei ir prevencijai gerinti“. Žin., 1996, Nr. 27-660.
} 
STT tapo nepriklausoma institucija ir buvo išplèstos jos funkcijos. STT buvo pavesta rengti ir igyvendinti korupcijos prevencijos priemones. $2000 \mathrm{~m}$. buvo ¡kurtas tarptautinès nevyriausybinès skaidrumo organizacijos Transparency International skyrius Lietuvoje.

Dar prieš $15 \mathrm{~m}$. apie korupcijos problemas Lietuvoje buvo kalbama pakankamai negarsiai. Strateginiuose dokumentuose korupcija buvo minima ekonominių nusikaltimų ir organizuoto nusikalstamumo kontekste ${ }^{24}$. Nè viena iš tuometinių ịtakingiausių partijų „kovai“ su korupcija neskyrẻ kokio nors ypatingo demesio, t. y. „kova“ su korupcija nelaikoma prioritetiniu uždaviniu atejus ị valdžią “25. Anot korupciją tyrinëjančio profesoriaus Dobrynino, politinèms partijoms trūko sisteminio požiūrio ị korupciją ir konkrečios antikorupcinès strategijos ${ }^{26}$. Galima sakyti, kad iki $2000 \mathrm{~m}$. korupcija nebuvo ypatingas klausimas, įtrauktas ị Lietuvos politinę darbotvarkę. Tačiau Lietuvos siekiai tapti Europos Sąjungos, NATO nare ir kitų tarptautinių organizacijų, tokių kaip Pasaulio bankas, ekonominiai interesai šią situaciją pakeitè.

Spartėjant deryboms su ES, daugejo iniciatyvų ir priemonių skirtų „kovai“ su korupcija. Stojimo ił ES proceso poveikis antikorupcinių instrumentų ir priemonių atsiradimui ir aktyviam kalbejimui apie korupciją Lietuvoje buvo akivaizdus. Korupcija kaip įsipareigojimas buvo minimas 1999, 2000 ir $2001 \mathrm{~m}$. Stojimo į ES partnerystėse. Pavyzdžiui $2001 \mathrm{~m}$. ES komisija ịpareigojo Lietuvą priimti ir igyvendinti antikorupcinę strategiją, Korupcijos prevencijos i̊statymą ir Valstybės tarnautojų etikos kodeksą, ratifikuoti atitinkamas tarptautines konvencijas. EK taip pat suteikè paramą formuojant Lietuvos antikorupcijos politiką, prisidèjo prie Nacionalinès kovos su korupcija programos ir jos sudedamųjų dalių - strategijos ir igyvendinimo plano, sukūrimo $2002 \mathrm{~m}$. Lietuvai finansinę ir žmogiškujjų išteklių pagalbą antikorupcinių veiklų igyvendinimui suteikẻ Europos Taryba, Europos Komisija, Tarptautinė Ekonominio bendradarbiavimo ir pletros organizacija, Pasaulio bankas ir kitos tarptautinès institucijos.

Aukščiau paminèti veiksniai didžiąją dalimi lèmè, kad korupcijos tema buvo aktualizuota politineje Lietuvos darbotvarkèje. Pavyzdžiui, 2001 m. Ministras pirmininkas išleido instrukciją, kad kiekvieną ekonominius santykius

\footnotetext{
${ }^{24}$ LR Vyriausybė, „Organizuoto nusikalstamumo ir korupcijos prevencijos programa“, http://tar.tic.lt/Default.aspx?id=2\&item=results\&aktoid=6812F764-BCD3-4113-A7CA-03D742ACB6E0, 20121123.

${ }^{25}$ „Transparency International“ Lietuvos skyrius, Ar Lietuva nori politinio skaidrumo? Itakingiausiu Lietuvos politiniu partiju antikorupciniu rinkiminiu programiniu nuostaty ir Lietuvos gyventojų nuomonès apie korupciją apžvalga, Vilnius. 2001, p. 14.

${ }^{26}$ BNS, Korupcijai skiriama per mažai dèmesio, $2001 \mathrm{~m}$. sausio $22 \mathrm{~d}$. http://www.delfi.lt/news/daily/lithuania/korupcijai-skiriama-per-mazai-demesio.d?id=174441\#ixzz2HHiwrD13, 20121119.
} 
reguliuojantị teisès normų projektą vyriausybè svarstytų tik po to, kai $\mathfrak{i}$ jị bus itraukti patarejo korupcijos ir muitų klausimais komentarai ir rekomendacijos $^{27}$.

Korupcijos problemos aktualizavimo apraiškų galime rasti skirtinguose nacionaliniuose dokumentuose - istatymuose, nutarimuose, strategijose, Vyriausybinès programose $\mathrm{e}^{28}$, taip pat ir tyrimuose. Svarbu pastebèti, kad korupcijos kaip problemos ir grésmés aktualizavimas nesibaigè, jis vyksta nuolat, skirtinguose lygmenyse ir skirtingomis formomis. Korupcija ir jos kontrolè Lietuvos politinëje darbotvarkèje užima vieną svarbiausių vietų tarp kitų socialinių problemų iki šiol.

\section{Korupcijos objektyvacija}

Vienas iš pagrindinių korupcijos reiškinio objektyvacijos elementų yra korupcijos apibrežtis. Anot Quinney, nusikaltimo apibrèžtis ir platesnè jo koncepcija yra labai svarbūs elementai nusikaltimo konstravimo procese. Korupcijos apibrèžtys atitinka esmines antikorupcinés politikos kryptis, o taip pat ir veikejjų, dalyvaujančių atsirandant apibrèžčiai, interesus.

Lotynų kalboje žodis corruptio reiškia gadinimą, supuvimą, papirkimą. Lietuvoje ilgai nebuvo susitarta dèl korupcijos apibrèžimo. Galima rasti tik pavienius bandymus apibūdinti korupciją. 1997 m. LR specialiųjų tyrimų tarnybos ${ }^{29}$ istatyme korupcija suprantama kaip valstybès tarnyboje vykstantys korupcinio pobūdžio pažeidimai. Pilnas korupcijos apibūdinimas yra pakankamai platus, ilgas ir be papildomo aiškinamojo rašto sunkiai suprantamas. 1999 m. Organizuoto nusikalstamumo ir korupcijos programoje pažymima, kad korupcija susijusi su pareiginiais nusikaltimais ir organizuotu nusikalstamumu. Programoje yra akivaizdus organizuoto nusikalstamumo ir korupcijos gretinimas, nurodantis apie šių nusikaltimų (problemų) tarpusavio ryš̨̌ $\mathfrak{c}^{30}$. Skirtinguose Lietuvos teisiniuose dokumentuose ${ }^{31}$ buvo apibrèžiamos tik atskiros korupcijos pobūdžio nusikalstamos veiklos. Korupcijos apibrèžties nebuvimo

\footnotetext{
${ }^{27}$ Atviros visuomenès institutas, (note 7) p. 91.

${ }^{28}$ Pavyzdžiui, LR Vyriausybės 2006-2008 metų programoje korupcijos kontrolè ịvardijama kaip veiklos prioritetas.

${ }^{29}$ LR Seimas, Specialiuju tyrimu tarnybos istatymas, http://www3.1rs.1t/pls/inter3/dokpaieska. showdoc_1?p_id=302323\&p_query=\&p_tr2=, 20121201.

${ }^{30}$ LR Vyriausybè, (note 22).

${ }^{31}$ LR Seimas, Korupcijos prevencijos istatymas, http://www3.1rs.1t/pls/inter3/dokpaieska.showdoc_1?p_ $\mathrm{id}=436086,20130102$.
} 
problema Lietuvoje buvo ne kartą akcentuota ${ }^{32} .2002 \mathrm{~m}$. Nacionalinėje kovos su korupcija programoje korupcijos samprata nebuvo pateikta, tačiau siūloma parengti tikslų teisinį korupcijos apibrèžimą, apimantị ir privatų sektorių. Šị siūlymą vèliau aktyviai rèmé nevyriausybiné skaidrumo organizacija „Transparency International" Lietuvos skyrius ir ragino ji atlikti Europos Taryba, tačiau iki šiol jis nèra ịgyvendintas. Nors bandymų būta: LR Vyriausybès 2006-2008 metų programoje pažymima, kad yra labai svarbu „užkirsti kelią korupcijai valdžios institucijose, nesąžiningai konkurencijai versle, tobulinti viešųjų pirkimų praktiką, sugriežtinti bausmes korumpuotiems pareigūnams ir sustiprinti finansinių nusikaltimų prevenciją “33. Korupcija šiame dokumente suprantama platesniame kontekste - ir valstybès, ir verslo sektoriuose. Penkioliktoji Vyriausybė savo programoje išskyre korupciją kaip prioritetinę sriti. Korupcijos problema programoje naudojama gero valstybės valdymo ir ekonominės raidos kontekste.

Naujausioje LR Nacionalinès kovos su korupcija 2011-2014 m. programoje korupcijos samprata ir toliau koncentruojasi $\mathfrak{i}$ valstybès tarnybą, joje dirbantys asmenys, patenkantys ị korupcijos apibrezžti, yra smulkiai aprašomi.

Nacionalinèse saugumo strategijose (2002, 2005 ir 2012 m.) korupcija suprantama kaip grėsmė, pavojus ir iššūkis. Pirmosiose strategijose pažymima, kad korupcijos kontrolè ir mažinimas yra svarbūs dèl valstybès politinių ir ekonominių interesų, o paskutiniojoje - ir dèl pilietinių interesų.

Lietuvos Prezidentès metiniuose pranešimuose (2010-2012 m.) korupcija vadinama trikdžiu, negalia ir siautuliu. Minimos tik atskiros korupcijos formos: kyšis, piktnaudžiavimas tarnyba, korupcinè veikla (2011 m.).

Viešojoje erdvejje aktyviai veikiančios nevyriausybinès organizacijos „Transparency International“ Lietuvos skyrius nuo savo issikūrimo $2000 \mathrm{~m}$. naudojo bene patị plačiausią Lietuvoje korupcijos apibréžimą: piktnaudžiavimas viešaja galia siekiant asmeninès naudos. Tokio apibrèžimo ašis - viešasis interesas. Šis korupcijos reiškinio apibrěžimas leidžia kalbèti apie korupciją visuose sektoriuose: valstybès, verslo ir nevyriausybiniame.

STT šiuo metu nurodo tokius savo veiklos prioritetus, korupcinių veikų, susijusių su viešaisiais pirkimais, vykdomais iš valstybès, savivaldybių biudžetų ir ES lěšų, užkardymas ir prevencija; korupcinių veikų, susijusių su administracinès priežiūros ir kontrolès vykdymu, užkardymas ir prevencija, ypač statybos, aplinkosaugos srityse. Šie prioritetai yra svarbūs, siekiant suvokti Lietuvos pastangų mažinti korupciją kryptis.

\footnotetext{
${ }^{32}$ LR užsienio reikalų ministerija, LR valstybès saugumo departamentas, Korupcinès situacijos Lietuvoje preliminarinis ivvertinimas bei kovos su korupcija strategijos metmenu parengimas, Vilnius, 1999, p. 4. ${ }^{33}$ Keturioliktosios LR Vyriausybès 2006-2008 metų programa, http://www.lrv.lt/bylos/vyriausybes/14vyr-dok/14-programa.pdf, 20121114.
} 
Taigi, pirmosios antikorupcinès priemonès Lietuvoje buvo kuriamos ir igyvendinamos net neturint aiškaus korupcijos apibrèžimo. Iki šiol Lietuvos teisiniuose dokumentuose korupcija buvo ir yra apibrèžiama siaurame teisiniame kontekste. Korupcijos problema siejama su valstybės sektoriumi ir asmenimis, dirbančiais valstybės tarnyboje. Korupcija versle iki šiol neturi tinkamo apibrěžimo, kuris leistų kriminalizuoti korupciją Lietuvos privačiame sektoriuje. Problemos, anot ekspertų, glūdi ne visiškai aiškioje valstybès tarnautojo ar jam prilyginto asmens sampratoje ${ }^{34}$. Tačiau reikia pastebèti, kad jau pastaraisiais metais procedūrinis korupcijos problemos suvokimo kontekstas tapo platesnis. Korupcija vis dažniau minima ekonominiame ir socialiniame kontekstuose, o korupcijos kaip grèsmès leitmotyvas naudojamas ne tik saugumo politikoje, bet ir platesniame kontekste.

Nagrinejjant kitą korupcijos objektyvacijos elementą - korupcijosdiagnostiką, pastebėtina, kad korupcijos situacijai Lietuvoje pristatyti buvo ir yra naudojami tarptautinių organizacijų Transparency International, Pasaulio Banko, Europos Komisijos Eurobarometro tyrimai, Freedom House ataskaitos ir nacionaliniai korupcijos tyrimai, kurių daugumą atliko „Transparency International“ Lietuvos skyrius ir Specialiụjų tyrimų tarnyba. Kadangi korupcija buvo sukonstruota kaip pamatuojamas fenomenas, korupcijos tyrimų instrumentai ir rezultatai tapo tam tikrais šio reiškinio įrodymais ir gali būti analizuojami kaip korupcijos fenomeno objektyvacijos dalis. Yra įvairių korupcijos diagnostikos būdų. Bene plačiausia prasme korupcijos tyrimai gali būti skiriami ị korupcijos suvokimo ir asmeninès patirties tyrimus, viešujų išlaidų stebėjimą ir kriminalinę statistiką ${ }^{35}$. Lietuvoje dažniausiai yra atliekami korupcijos suvokimo ir asmeninès patirties tyrimai, kai ị apklausas įtraukiamos skirtingos visuomenès grupès: valstybės tarnautojai, verslo atstovai, visuomené plačiąją prasme ir atskirų sektorių (medicinos, farmacijos, miškų, žiniasklaidos, ES paramos ir kt.) atstovai.

Aptariant nacionalinius korupcijos tyrimus, reikia paminèti vieną pirmụjų reprezentatyvią gyventojų apklausą apie kyšininkavimą. Ji buvo atlikta 1999 m. ${ }^{36}$. Tai, kad dažnai duoda kyši valstybès pareigūnui prisipažino 4 proc. Lietuvos gyventojų, 73 proc. teigè, kad niekada nedavẻ kyšio. Buvo tiriamas tik kyšininkavimas valstybès tarnybos kontekste. Jau po 2-3 m. šie rodikliai žymiai padidejo ir tai turi būti vertinama ne tik blogejjančios situacijos, bet ir

\footnotetext{
${ }^{34}$ Zaksaite S., „Korupcijos privačiame sektoriuje kriminalizavimo problemos“, Verslo ir teisés aktualijos, 2012, 7 (2), p. 333-350.

${ }^{35}$ Holmes L., Rotten States?: Corruption, Postcommunism, And Neoliberalism. Duke University Press, 2006, p. 1-16.

${ }^{36}$ Apklausą atliko visuomenès nuomonès ir rinkos tyrimų centras „Vilmorus“.
} 
¿̇sibėgèjančios antikorupcijos pramonès ${ }^{37}$ kontekstuose. Per pastaruosius dvylika metų Lietuvoje buvo atlikta daugiau nei 30 korupcijos suvokimo ir patirties tyrimų, kurių pagrindas reprezentatyvios Lietuvos gyventojų ar atskirų profesinių ar socialinių grupių apklausos ${ }^{38}$.

Vienas didžiausių ir žinomiausių nacionalinių korupcijos tyrimų „Lietuvos korupcijos žemelapis“ (LKŽ) yra atliekamas nuo $2001 \mathrm{~m} .{ }^{39}$ Iš viso yra atlikti septyni korupcijos žemèlapio tyrimai 2001-2011 m. laikotarpiu. „Korupcijos žemèlapio“ pamatas - nacionalinės sociologinès apklausos ir ekspertiniai vertinimai. Šiuo tyrimu yra siekiama nustatyti ịvairių socialinių grupių požiūrị ị institucinị ir geografinị korupcijos paplitimą Lietuvoje, jų patirtị susiduriant su korupcijos atvejais, o taip pat ivertinti Lietuvos visuomenès antikorupcini potencialą. Nuo $2008 \mathrm{~m}$. sociologinèse apklausose dalyvauja ne tik Lietuvos gyventojai ir i̇monių vadovai, bet ir valstybès ir savivaldybių tarnautojai. Pirmụjų šešiu minètų tyrimų rezultatų analizè atskleidè, kad Lietuvos korupcijos žemèlapis keičiasi nežymiai. Nors antikorupcinis potencialas pamažu stiprèja, žmonių nuostatos ir patirtis liudija apie išliekantị pakantumą

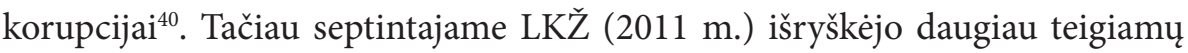
tendencijų nei ankstesniais metais:

- palyginti su $2001 \mathrm{~m}$. ir vèliau atliktų tyrimų rezultatais, $2011 \mathrm{~m}$. buvo daugiausiai teigiančių, kad korupcijos mastai sumažèjo.

- Nuosekliai mažèjo (nors neženkliai) Lietuvos gyventojų ir verslininkų, davusių kyši, dalis.

- Praktiškai visose valstybinėse institucijose, su kuriomis dažniau susiduria Lietuvos gyventojai (ne mažiau 100 respondentų), kyšių prievartavimo ir kyšių davimo indeksai konkrečiose institucijose, palyginti su 2008 m., sumažèjo.

\footnotetext{
${ }^{37}$ Antikorupcijos pramonę charakterizuoja korupcijos problemos sureikšminimas politinèje darbotvarkèje: gausios tarptautinės iniciatyvos, skiriamas didelis dėmesys korupcijos problemai šalių vyriausybių programose, stiprus pilietinès visuomenès ịsitraukimas ị problemos sprendimą ir šioms iniciatyvoms pritraukiami dideli resursai. Šios pramonès institucionalizacija politinèje arenoje vyksta per antikorupcinių organizacijų veiklą, konferencijas, konvencijas, o taip pat naudojant akademinį diskursą, diagnostikos įrankius, progreso ataskaitas ir t. t. Dèl to pagaminami standartizuoti produktai: žinios, matavimo įrankiai, ìvairios veiklos.

${ }^{38}$ Dauguma korupcijos tyrimų atliko „Transparency International“ Lietuvos skyrius. Juos galima rasti

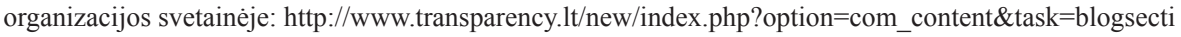
on\&id=2\&Itemid=9 ir STT - http://www.stt.lt/lt/menu/sociologiniai-tyrimai/

${ }^{39}$ Šio kompleksinio sociologinio korupcijos tyrimo metodologiją sukūrè Vilniaus universiteto mokslininkai: prof. Aleksandras Dobryninas, dr. Laimute Žilinskienė ir dr. Rasa Ališauskienė. Autoriai ją aprašè knygoje Lietuvos korupcijos žemèlapis 2001-2004, 2005, Vilnius: Eugrimas.

${ }^{40}$ Aleknevičienė J., „Kaip keičiasi Lietuvos korupcijos žemėlapis?” žr. Muravjov S., sudar., Korupcijos mįslès, Vilnius: Eugrimas. 2009, p. 29.
} 
- Nuo 2004 m. daugèjo gyventojų, kurie teigia, kad nedavė kyšio, nes tai prieštarauja mano įsitikinimams.

- Padidèjo verslininkų, norinčių dalyvauti antikorupcinèje veikloje, skaičius. Tarp Lietuvos gyventojų aktyviụjų skaičius praktiškai nesikeičia ${ }^{41}$.

$2011 \mathrm{~m}$. pagal „Transparency International“ metodologiją buvo atliktas ir Lietuvos nacionalinès atsparumo korupcijai sistemos tyrimas, kurio tikslas ¡̇vertinti, kiek Lietuvos valstybinės institucijos, privatus ir nevyriausybinis sektoriai yra atsparūs korupcijai. Tyrime buvo apžvelgtas 2009-2011 m. laikotarpis. Tyrimą atliko penkiolikos tyrejų ir jų padejjejų grupé, kuriai vadovavo Teisès institutas. Tyrimo išvada skelbė, kad Lietuvos atsparumo korupcijai sistema veikia ganètinai gerai $^{42}$.

Nepaisant nors ir nedidelių, bet teigiamų tendencijų, kurias fiksuoja vieni didžiausių korupcijos tyrimų Lietuvoje, viešojoje erdvèje buvo galima rasti priešingų situacijos vertinimų, pavyzdžiui, tuo pat metu Lietuvos Prezidente teigè, jog korupcija Lietuvoje pradeda paralyžiuoti valstybės vystymąsi ${ }^{43}$.

Vienas žinomiausių korupcijos suvokimo tyrimų pasaulyje yra „Transparency International“ Korupcijos suvokimo indeksas (toliau - KSI), nustatomas remiantis verslo atstovų apklausomis ir kitais ekspertiniais tyrimais. Šio ir kitų tyrimų rezultatai yra suprantami kaip iliustracija, dèl kurios korupcijos reiškinys yra objektyvuojamas tam tikroje šalyje. KSI yra labai populiarus Lietuvoje, gausiai ir garsiai aptariamas, ịtraukiamas kaip rodiklis ị valstybės i̊staigų veiklos planus ir nacionalines programas. Lietuvos KSI skaičiuojamas nuo $1999 \mathrm{~m}$. Šio tyrimo centre yra viešasis sektorius ir valstybès tarnautojai ir politikai. Iki $2011 \mathrm{~m}$. KSI vertindavo šalis pagal dešimties balų skalę, o 2012 m. esama padètis pradèta vertinti pagal šimto balų skalę, kurioje 0 reiškia absoliučiai korumpuotą šalį, o 100 - labai skaidrią valstybę. Korupcijos padèties vertinimus atlieka tiek vertinamose šalyse, tiek svetur gyvenantys ekspertai ir verslo lyderiai. 2012 metų KSI yra skaičiuojamas pagal atnaujintą metodologiją, kurioje naudojami tik vienerių metų duomenys kiekvienam šalies KSI šaltiniui. Nepaisant to, kad šis vienas žinomiausių korupcijos suvokimo tyrimų pasaulyje nuolat patirdavo ideologinius virsmus ir tuo sąlygodavo meto-

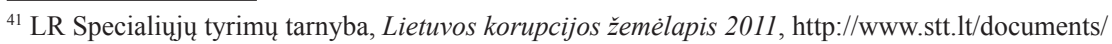
soc_tyrimai/Korupcijos_zemelapis.pdf, 20121108.

42 „Transparency International“ Lietuvos skyrius, Lietuvos nacionalinès atsparumo korupcijai sistemos tyrimas, http://www.transparency.lt/new/images/lietuvos_nacionalines_atsparumo_korupcijai_sistemos_ tyrimas.pdf, 20121201.

${ }^{43}$ Veidas, D. Grybauskaitè: „,nereikètu savęs apgaudinèti, kad tuoj turèsime atominę elektrinę“, http:// www.veidas.lt/d-grybauskaite-nereiketu-saves-apgaudineti-kad-tuoj-turesime-atomine-elektrine, 201211 16.
} 
dologines abejones, visgi nacionaliniu mastu buvo kaip pamatinis ir sureikšminamas $^{44}$. Reikia pastebèti, kad nuo 2009-2010 m. Lietuvos KSI didèjo, t. y. Lietuva buvo vertinama kaip skaidresnè valstybè, $2011 \mathrm{~m}$. krito ir pasieké 2005-2007 m. rodikli, o $2012 \mathrm{~m}$. Lietuva per metus pakilo dviem padalom Korupcijos suvokime indekse. Tačiau Lietuvos KSI komentarai viešojoje erdveje dažniausiai buvo susiję su neigiamu Lietuvos vertinimu, pavyzdžiui, $2012 \mathrm{~m}$. „Transparency International“ Lietuvos skyriaus vadovas teigè, kad „pastaruosius kelerius metus bandau izžvelgti ką nors teigiamo Lietuvos KSI tyrimo rezultatuose, tačiau, prisipažinsiu, tai sunku padaryti ${ }^{\text {“45 }}$.

Nacionaliniuose tyrimuose fiksuojami teigiami korupcijos kontrolès ir mažinimo ženklai, neatsispindi ir Freedom House ataskaitoje „Nations in Transit“, kur šalys grupuojamos pagal demokratijos praktiką. Kasmetinis vertinimas atliekamas nuo 1997 m. dvidešimt aštuoniose Vidurio, Rytų ir Pietinès Europos šalyse. Šalys vertinamos 7 balų skaleje, kai 1 reiškia aukščiausią demokratijos išsivystymą, o 7 - žemiausią. Tai, kad korupcija yra vienas iš septynių Freedom House vertinimo kriterijų rodo, kad jau nuo 1999 m. šio reiškinio buvo pradėta ieškoti visose tiriamose pereinamojo laikotarpio šalyse, tarp jų ir Lietuvoje. Lietuva korupcijos situacijos požiūriu patenka tarp blogiausiai ịvertintų šalių (vertinimas nesumažejo mažiau nei 3.5 balo, o 2006-2009 m. buvo dar prastesnis). $2012 \mathrm{~m}$. vertinimas, kuris apèmè $2011 \mathrm{~m}$. laikotarpi, buvo 3.5 balai. Verta atkreipti dèmesí, kad $2012 \mathrm{~m}$. Lietuvos korupcijos situacijos ataskaitą rengè vienas ekspertas iš Lietuvos. Dauguma ataskaitoje naudojamų šaltinių buvo žiniasklaida. Nors Freedom House ataskaitos susilauke kritikos ${ }^{46}$, visgi tarptautinejje erdvejje buvo ir ji yra vienas iš ịrankių "Lietuvos tikrovei“ konstruoti.

$2012 \mathrm{~m}$. paskelbto Eurobarometro tyrimo ${ }^{47}$ duomenimis bent aštuoni iš dešimties Lietuvos gyventojų manè, kad korupcija yra viena iš didžiausių šalies problemų. Palyginti su kitomis šalimis pagal šį rodiklį Lietuva yra devinta. Lietuva kartu su Slovakija ir Rumunija šio tyrimo kontekste taip pat pirmauja ir tarp šalių, kurių respondentai tvirtino, kad iš jų buvo prašyta ar tiketasi kyšio.

\footnotetext{
${ }^{44}$ Delfi, Korupcijos suvokimo indeksas Lietuvoje nesumažèjo, bet G. Kirkilas atsistatydinti nežada, http:// www.delfi.lt/news/daily/lithuania/korupcijos-suvokimo-indeksas-lietuvoje-nesumazejo-bet-gkirkilasatsistatydinti-nezada.d, 20121108.

45,"Transparency International“" Lietuvos skyrius, Lietuva per metus pakilo dviem vietomis ,,Transparency International " Korupcijos suvokimo indekse, http://www.transparency.lt/new/index.php?option=com_con tent\&task=view\&id=11277\&Itemid=25, 20121205.

${ }^{46}$ Bernardinai.lt, K. Girnius. Lietuvos demokratijos ịvertinimas priklauso nuo vertintojų, http://www. bernardinai.lt/straipsnis/2007-09-27-k-girnius-lietuvos-demokratijos-ivertinimas-priklauso-nuo-vertintoju/27468, 201211 08. Aleknevičienè J., „Kalbèjimo apie korupciją žala“, 2007.

${ }^{47}$ European Commission, http://ec.europa.eu/public_opinion/archives/ebs/ebs_374_en.pdf, 20121205.
} 
Reaguodama ị Eurobarometro duomenis EK narè teigè, kad „praktiniai kovos su korupcija rezultatai visoje Europoje tebera nepatenkinami. Kiek kartų sakème, kad būtina imtis veiksmų? Europiečiai tikisi, kad nacionalinès vyriausybès imsis ryžtingų veiksmų. Atèjo laikas tą padaryti“"48.

Apibendrinant pažymėtina, kad Lietuvos korupcijos žemèlapis keičiasi lètai, reikia laiko nuostatų ir vertybių pokyčiams užfiksuoti. Pagrindinio kompleksinio Lietuvos korupcijos tyrimo "Lietuvos korupcijos žemèlapis“ koncepcija kito, tačiau metodologinis pagrindas išliko stabilus ir leidžia gauti patikimus palyginamuosius rezultatus. Tačiau verta paklausti, kiek šis tyrimas naudojamas antikorupcinèms praktikoms Lietuvoje kurti ir Lietuvos pastangu mažinti korupciją sklaidai tarptautineje erdvejje? Nors nacionaliniai korupcijos tyrimų rezultatai skelbia apie atsirandančias teigiamas tendencijas Lietuvoje, tarptautinių standartizuotų korupcijos tyrimų rezultatai Lietuvai yra nepalankūs. Tuo remiantis tarptautiniai ir nacionaliniai veikèjai naudoja nekontroliuojamos, neįveikiamos ir visa žlugdančios korupcijos retoriką ir kviečia dar aktyviau „kovoti“ su korupcija. Svorio tarptautiniams tyrimams suteikia ir ịtakingų Lietuvos politinių veikèjų vieši nekritiški komentarai: 2006 m. ministras pirmininkas Gediminas Kirkilas Žinių radijo laidoje žadejjo atsistatydinti, jei Lietuvos korupcijos indeksas nesikeis ị teigiamą pusę, $2008 \mathrm{~m}$. vienos ịtakingiausių partijų lyderis Andrius Kubilius teigè, kad partija pasižada siekti, kad po ketverių metų, igyvendinus naujosios viešosios vadybos principus, kad pagal "Transparency International” korupcijos indeksą Lietuva atsidurtų pirmajame dvidešimtuke, tarp mažiausiai korumpuotų valstybių." ${ }^{39}$ Nekritiškas požiūris ị standartizuotus antikorupcinius instrumentus iggalina tarptautinius "žaidejus" veikti ir toliau konstruoti „kovos“ su korupcija, instrumentus ir efektyvumo standartus, orientuotus $\mathfrak{i}$ bendruosius tarpkultūrinius, o ne nacionalinius ypatumus, bei igyvendinti savo interesus.

\section{Korupcijos eksternalizacija}

Galima išskirti keletą svarbiausių korupcijos problemos eksternalizacijos elementų: antikorupcinès strategijos, programos, antikorupciniai projektai, mokymai ir kt. Apžvelgsime pagrindinius, dalyvaujančius korupcijos fenomeno konstravimo procese.

\footnotetext{
${ }^{48}$ EurActiv.lt, Eurobarometras. Korupcija didejja?, http://www.euractiv.lt/lt/straipsnis/4799/eurobarometras-korupcija-dideja, 20121110.

${ }^{49}$ Veidas, Seimas mojuoja nauju popieriniu antikorupcijos kardu, http://www.veidas.lt/seimas-mojuojanauju-popieriniu-antikorupcijos-kardu 20121108.
} 
2002 m. LR Seimas, vadovaudamasis Nacionalinio saugumo pagrindų ịstatymu, patvirtino Nacionalinę kovos su korupciją programą ir jos priemonių planą. Programos tikslas buvo sumažinti korupciją Lietuvoje, siekti, kad ji kuo mažiau trukdytų plètoti ekonomiką, demokratiją, siekti socialinès gerovès ir stiprinti nacionalinị saugumą. Viena vertus, ši programa buvo pripažįstama kaip geros praktikos pavyzdys ${ }^{50}$, kita vertus, sulaukè kritikos dèl „Vakarų“ ir "Rytų“ antikorupcinių praktikų sankirtos ${ }^{51}$. Programoje buvo naudojami tiek nacionaliniai, tiek tarptautiniai korupcijos situacijos tyrimų duomenys ir rodikliai, akcentuojamas tarptautinių organizacijų indèlis ir nacionalinès antikorupcinès teisinès bazès dermès su tarptautiniais dokumentais, ypač ES, siekis. Programoje atsispindejo Pasaulio banko „politinès“ ir "administracinès“ korupcijos sampratų išskyrimas. Ypatingas dèmesys buvo skiriamas administracinei korupcijai ir jos prevencijai. Pažymètinas kovinès retorikos naudojimas visose nacionalinèse korupcijos mažinimo programose.

Vèlesnè ir iki šiol galiojanti, $2011 \mathrm{~m}$. Nacionalinè kovos su korupcija programa siekia užtikrinti veiksmingą ir kryptingą korupcijos prevencijos sistemą Lietuvoje ir stiprinti nacionalinị saugumą. Programoje bendrajai aplinkos analizei atlikti buvo naudojama kriminalinè statistika ir tarptautiniai tyrimai, kurie, kaip jau buvo minèta, nepelnytai sureikšminami Lietuvoje, o atskiroms sritims - derinami tarptautiniai rodikliai su nacionaliniais. Pastaroji programa, kaip ir iki šiol buvusios, daugiausia orientuojasi į valstybès tarnybą ir asmenis dirbančius joje. Privačiam sektoriui dèmesio skiriama nedaug. I programos laukiamų rezultatų vertinimą îtraukiamos skirtingų socialinių grupių (valstybès tarnautojų, verslininkų, gyventojų) nuomoné. Analizuojant 2011-2014 m. programos struktūrą, pastebètina, kad joje visų pirma, antikorupciniu požiūriu yra ịvertinami politiniai ir teisiniai veiksniai, kuriuos būtų galima sąlyginai pavadinti politiniais interesais, antras prioritetas yra skiriamas ekonominiams interesams ir tolesni - socialiniams ir technologiniams ${ }^{52}$.

Korupcijos problema taip pat minima ir visose Nacionalinèse saugumo strategijose. $2002 \mathrm{~m}$. strategijoje korupcija buvo paminèta tarp dvylikos iššūkių, pavojų ir grèsmių. Kova su organizuotu nusikalstamumu ir korupcija

\footnotetext{
${ }^{50}$ Steves Fr., Rousso A., ,Anti-corruption programmes in post-communist transition countries and changes in the business environment, 1999-2002", European Bank for Reconstruction and Development. Working Paper No. 85, 2003.

${ }^{51}$ Dobryninas A., „Lithuania“s Anti-corruption policy: Between the „West” and the „East”?, European Journal on Criminal Policy and Research, Vol. 11, 2005, p. 77-95.

${ }^{52}$ LR Seimas, Lietuvos respublikos Nacionaline kovos su korupcija 2011-2014 metu programa, http:// www3.lrs.lt/pls/inter3/dokpaieska.showdoc_1?p_id=402714, 20121102.
} 
pažymima kaip vienas didžiausių prioritetų užtikrinant Lietuvos nacionalinị saugumą. Strategijoje korupcijos problema atsispindi politiniame - t. y. Lietuvos siekio tapti ES nare kontekste. $2005 \mathrm{~m}$. strategijoje korupcija taip pat minima kaip viena iš grèsmių nacionaliniam saugumui ir apibūdinama politinių ir ekonominių (ES paramos skaidrumo užtikrinimas, finansinių nusikaltimų prevencija ir kontrolè) interesų kontekste. 2012 m. strategijoje korupcija atsidūre šalia kitų ypatingo dẻmesio reikalaujančių socialinių ir ekonominių problemų - nenuoseklios socialinès ir ekonominès raidos ir didelès gyventojų emigracijos. Šioje strategijoje galima įžvelgti tiek politinius, tiek ekonominius, tiek pilietinius aspektus „kovoje“ su korupcija.

Lietuvos Prezidentė savo metiniuose pranešimuose kalba apie „siautėjančią korupciją" ir "negailestingą karą korupcijai“ naudodama aštrią kovinę retoriką. 2010 m. pranešime pabrežiama Valstybès tarnautojo elgesio kodekso ir Lobistinès veiklos ir poveikio teisès reglamentavimo, visuomenès indèlio svarba ir teismų vaidmuo „kovoje“ su korupcija. 2011 m. pranešime teigiama, kad korupcija yra „giliausiai ịsišaknijusi ir sunkiai gydoma mūsų negalia“, „kyšis, piktnaudžiavimas tarnyba, korupcinè veikla" gali egzistuoti tol, kol mes - visuomenè - tą pakenčiame “53. Pastebėtinas trijų korupcijos reiškinio elementų ǐ̌skyrimas, kuriuos reikia suprasti kaip esminius ar prioritetinius, tačiau nesuteikiančius tikslesnès ar konkretesnès informacijos. 2012 m. pranešime korupcija minima teismų ir sèkmingos kovos pradžios su korupcija ir korupcijos kaip trikdžio „kad korupcija nekištų pagalių $i$ ratus" kontekstuose. Akivaizdu, kad Prezidentès metiniuose pranešimuose korupcija atranda savo vietą, tačiau pasisakymuose yra daug neapibrèžtumo ir griežto tono, kuris liudija, kad korupcijos problema yra ypatinga ir aktuali nepaisant visų pastangų ir vykdomų priemonių.

Korupcijos problema itin aktualizuojama ir Vyriausybès programose ${ }^{54}$. Analizuojant naujosios šešioliktosios Vyriausybès programą, pastebètina, kad „kova“ su korupcija yra minima tarp neatidèliotinų veiklos prioritetų ekonominio intereso kontekste. Be to, „kovai“ su korupcija yra skirtas atskiras skyrius, kuriame akcentuojama visų galimų veikèjų - valdžios, visuomenès, žiniasklaidos, verslo, religinių ir kitų organizacijų sutelkimas įtraukant juos ị korupcijos atvejų atskleidimą. „Psichologinio ir pilietinio viešosios sąmonès antikorupcinio lūžio ir nepakantumo korupcijai" akcentavimas yra nuoroda $\mathfrak{i}$ tikètinus vertybių ir nuostatų pokyčius, kurių bus siekiama ne švietimo, o bau-

\footnotetext{
${ }^{53}$ LR Prezidente, LR Prezidentès Dalios Grybauskaitès metinis pranešimas $2011 \mathrm{~m}$. birželio 7 d., http:// www.president.lt/lt/prezidento_veikla/metinis_pranesimas/2011_m..html, 20121108.

${ }^{54}$ Pavyzdžiui, $2012 \mathrm{~m}$. Vyriausybè vienu svarbiausiu siekių įvardijo kovą su korupcija valdžios sektoriuje (užtikrinti valstybės ir savivaldybių institucijų ir įstaigų veiklos (priimamų sprendimų, viešujų finansų naudojimo, išduodamų dokumentų, teikiamų paslaugų) viešumą (Žin., 2011, Nr. 126-5592).
} 
džiamosiomis priemonėmis (siūloma kriminalizuoti pakantumą korupcijai). Pastebėtina, kad programoje stokojama sąsajų tarp antikorupcinių veiksmų ir toje pačioje programoje deklaruojamų vertybių.

Taigi, aukščiau paminètos „kovos“ su korupcija programos ir strategijos buvo pagrindas kitoms antikorupcinèms programoms, kurias vykdè ir vykdo valstybinès institucijos. Panašias kuria ir ịgyvendina verslo ịmonès, mokslo ịstaigos ir tarptautinės organizacijos. Anot ekspertų „,rytų Europa buvo vertinga niša antikorupcijos „pramonei“ ${ }^{\text {“55 }}$, Lietuva šiuo požiūriu nebuvo išimtis. Reikia pastebèti, kad ypatingai pirmosios strategijos ir programos buvo labai deklaratyvios, su neipareigojančiais veikti ir abstrakčiais tikslais, be išpletoto turinio. Pagrindiniu ir pirmuoju „kovos“ su korupcija strategijų, programų ir pranešimų taikiniu buvo valstybės tarnautojai, nors šiu strategijų ir programų tikslai buvo nukreipti beveik i kiekvieną visuomenès narị. Kiek vèliau pradètas pamažu akcentuoti ir verslo sektorius. Korupcijos ir kyšininkavimo prevencija ar mažinimas buvo pažymimos kaip atskiros problemos, nors kyšininkavimas yra viena iš korupcijos formų. Taigi, „strategijos, planai, projektai, ataskaitos, komisijos, darbo grupès, pasitarimai, susitikimai...<...> kaip ir daugelis šalies problemų, taip ir ši ima skęsti popierizmo liūne" dar $2006 \mathrm{~m}$. teigè buvęs Valstybės saugumo departamento vadovas ${ }^{56}$.

Pastebètina ir kitokių antikorupcinių iniciatyvų apraiškų: pavyzdžiui, $2007 \mathrm{~m}$. buvo ịkurtas Kovos su korupcija frontas, žinomas kaip oponentas konkrečiai Atominès elektrinès steigimo temai. 2009 m. buvo ịsteigtas Antikorupcijos švietimo centas, kuris vykdo projektinę veiklą be konkrečios specializacijos. Pastarieji pavyzdžiai liudija ir apie „kovos“ su korupcija politizavimą ir ekonominę naudą.

Apibendrinant galima skirti tris „kovos“ su korupcija vajaus etapus Lietuvoje:

- aktyvusis, apimantis 1998-2004 m. Pagrindiné šio etapo varomoji jèga buvo Lietuvos integracija į ES.

- Prislopintas (2004-2008), kurị sąlyginai galima pavadinti „kovos“ su korupcija rezultatų laukimu. Matomi nevyriausybinių organizacijų bandymai kurti Pilietinį aljansą prieš korupciją ir kelti kritiškus klausimus „kiek dar reikia įstatymų korupcijai pažaboti?" ${ }^{\text {57 }} .2006$ m. spalio mèn. buvo pasirašytas parlamentinių partijų frakcijų susitarimas dèl Kovos su

\footnotetext{
${ }^{55}$ Michael B., ,The Rise and Fall of the Anti-Corruption Industry: Toward Second Generation Anti-Corruption Reforms in Central and Eastern Europe?" Local Governance Brief. Policy Journal of the Local Government and Public Service Reform Initiative, 2003, p. 1.

${ }^{56}$ Jurgis Jurgelis, Kovos su korupcija fronte, Bernardinai.lt, http://www.bernardinai.lt/straipsnis/-/29891, 20121108.

${ }^{57}$ Žmogaus teisių stebèjimo institutas, Pilietinis aljansas prieš korupciją ieško būdu pažaboti korupcija Lietuvoje, http://www.hrmi.lt/naujiena/157/, 20121108.
} 
korupcija stiprinimo. Jame pripažịstama, kad korupcijos mastas šalyje yra netoleruotinas, o esamų antikorupcinių priemonių nepakanka, taip pat pabrèžiama kovos su korupcija stiprinimo prioritetinè svarba.

- Desperatiškasis etapas nuo 2008 m. Tai situacija kai „niekas neveikia“, o korupcijos problemos aktualumas tik dideja. Prezidentūroje buvo surengta konferencija „Korupcijos pažabojimo vizijos 2008“. Penkioliktoji Vyriausybė kovą su korupcija savo programoje išskyrè kaip prioritetinę sritị. Ministras Pirmininkas 2009 m. balandžio mèn. sudarè darbo grupę, kuri teiktų jam pasiūlymus, kaip mažinti korupcijos atsiradimo prielaidas. $2010 \mathrm{~m}$. Seimo rudens sesijoje „kova“ su korupcija buvo ịvardyta prioritetu, o vienuolikos ịstatymų projektai, prisidesiantys prie korupcijos mažinimo, programoje buvo įrašyti pirmaisiais numeriais. $2011 \mathrm{~m}$. Lietuvos Prezidente teigè, kad „korupcija plinta kaip vė̌ys“"58 ir Lietuvos žmonès nepastebejjo kovos su korupcija ${ }^{59}$. Taigi, antrame straipsnio skyriuje paminèti $2011 \mathrm{~m}$. fiksuojami korupcijos situacijos gerẻjimo ženklai galèjo tapti sèkmės etapo pradžia, tačiau taip neịvyko. „Kovos" su korupcija matomumą ir poreikį didino ir antikorupcinès retorikos išsiplètimas - šalia gero valdymo, viešojo administravimo ir etikos atsirado skaidrumo, integralumo, antikorupcijos, patikimumo, sąžiningumo ir kitos susijusios temos. Vis garsiau Lietuvoje buvo ir yra minima Tarptautiné antikorupcijos diena. Jos proga yra organizuojami renginiai Vyriausybèje ${ }^{60}$, savivaldybėse, mokslo įstaigose. Universitetuose yra skaitomi antikorupcijos kursai, vedami seminarai ir mokymai. Lietuva siekia tapti Tarptautinės antikorupcijos akademijos ${ }^{61}$ nare, kuri yra ìsteigta Vienoje kaip novatoriškas nepriklausomų antikorupcinių mokymų ir mokslinių tyrimų centras. Akivaizdu, kad inercinè ir desperatiška „kova“ su „nenugalima“ korupcija tęsiasi ir neketina sustoti.

Akivaizdu, kad pastangos mažinti korupciją Lietuvoje tapo prioritetinès, projektizuotos ir gerai finansuojamos. Tačiau akivaizdu ir tai, kad Rytų ir Vidurio Europos šalys, tarp jų ir Lietuva, ịgyvendinančios didžiausią skaičių gero valdymo (administravimo) reformų ir antikorupcinių programų, iki šiol yra laikomos labiausiai korumpuotomis ES. Jau $2000 \mathrm{~m}$. korupcijos tyrèjai ir ekspertai pastebèjo, kad „egzistuoja antikorupcinių strategijų ir agentūrų kū-

\footnotetext{
${ }^{58}$ Delfi, D. Grybauskaité: korupcija plinta kaip véžys, http://www.delfi.lt/news/daily/lithuania/dgrybauskaite-korupcija-plinta-kaip-vezys.d?id=47479985, 20121108.

59 “Žmonès nepastebi kovos su korupcija”, Veidas, http://www.veidas.lt/zmones-nepastebi-kovos-sukorupcija, 20121108.

${ }^{60}$ LR Vyriausybè, Vyriausybès rūmuose bus apdovanotos geriausios antikorupcinès iniciatyvos, http:// www.lrv.lt/lt/naujienos/aktualijos/?nid=11490, 20121120.

${ }^{61}$ The International Anti-Corruption Academy, http://www.iaca-info.org/, 20121108.
} 
rimo vajus, neatsižvelgiama ị efektyvumo ir nenumatyto poveikio kriterijus ${ }^{62}$. Praejjus dešimtmečiui - šios tendencijos išlieka.

\section{Išvados}

Lietuva kaip ir kitos naujosios ES narès yra tarptautinių, visų pirma ES, antikorupcinių interesų lauke. ES vaidmuo igyvendinant antikorupcines priemones Lietuvoje pastaraisiais metais nemažeja.

Konstrukcionistinè korupcijos fenomeno konstravimo prielaidų Lietuvoje analizė atskleidè, kad Lietuvos „kova“ su korupcija igavo antikorupcinès pramonés pavidalą:

- Korupcija tapo universalia tema skirtingų interesų veikejjams: valstybès institucijoms, tarptautinèms organizacijoms, rinkos dalyviams ir pilietinès visuomenès atstovams. Korupcijos mažinimas ir kontrolè atsidūrè tarpvalstybinèse ir nacionalinèse politinèse darbotvarkèse.

- Globalūs standartizuoti antikorupciniai produktai - antikorupciniai paketai, apimantys žinias apie korupciją, matavimo instrumentus ir veiklas, yra taikomi ir Lietuvoje. Pažymėtina, kad tarptautiniai korupcijos diagnostikos instrumentai yra abstraktūs, kompleksiniai ir neatsižvelgiantys ì nacionalinius socio-kultūrinius ypatumus.

- Išaugo korupcijos problemos aktualizavimo laukas. Korupcija akcentuojama saugumo, nusikaltimų, socialinių problemų ir kt. kontekstuose. Siaura teisine korupcijos apibrèžtis, kurios pagrindinė ašis buvo kyšininkavimas, išsiplètè. Šalia pagrindinio korupcijos taikinio - valstybès sektoriaus, palaipsniui akcentuojami ir verslo, ir nevyriausybinis sektorius. Korupcija tapo tarpsektorine problema - antikorupciniu požiūriu yra vertinami įstatymų projektai, jų pataisos, nutarimai ir programos. Korupcijos mažinimui naudojama aštri kovinė retorika.

- Padaugejo „kovos“ su korupcija institucionalizacijos elementų: antikorupcinių susitarimų, konferencijų, diskusijų, konvencijų, programų, diagnostikos instrumentų.

- Antikorupcinése veiklose atsirado plačios kvalifikacijos specialistų - universalių projektų ir programų vadovų ir vykdytojų, galinčių dirbti tiek su korupcijos, tiek su kitomis socialinèmis problemomis. Pastariesiems problemos sprendimas rūpi mažiau nei asmeninè karjera. Šie specialistai savo darbo temą keičia priklausomai nuo laimètų projektų temos.

\footnotetext{
${ }^{62}$ Hellman J. S., Jones G., Kaufmann D., and Schankermann M.. Measuring Governance, Corruption, and State Capture, http://unpan1.un.org/intradoc/groups/public/documents/un-dpadm/unpan044602.pdf, 20121108.
} 
- Pasikeite ir išsiplète „kovos“ su korupcija retorika. Gero valdymo (viešojo administravimo) temas papildè socialinès atsakomybès, skaidrumo, integralumo, atskaitomybès, pasitikejjimo, atvirumo ir sąžiningumo klausimai. Šią retoriką naudoja ne tik valstybès, bet ir privatus, nevyriausybinis sektoriai, mokslo institucijos.

Taigi, kodèl nepastebime pažangos korupcijos mažinimo srityje?

- Pirma, paminètos globalios ir nacionalinès antikorupcijos „pramonès“ apraiškos padidina korupcijos matomumą Lietuvos visuomenéje.

- Antra, tarptautiniai korupcijos tyrimai Lietuvoje yra nepelnytai sureikšminami. Kai kurių tarptautinių institucijų atliekami korupcijos tyrimai neatlaiko rimtesnés kritikos, o korupcijos situacijos vertinimo ataskaitos, kaip, pavyzdžiui, Freedom House 2012, yra rengiamos vieno asmens, naudojant žiniasklaidą kaip pagrindinị šaltinị. Todèl Lietuvos tikslas visomis išgalèmis pagerinti Korupcijos suvokimo indeksą ar kitus tarptautinius sunkiai paaiškinamus antikorupcinius rodiklius ir tokiu būdu fiksuoti pažangą, gali likti nepasiektas ir iki Lietuvos pažangos strategijoje numatytų tikslų $2030 \mathrm{~m} .{ }^{63}$ Vietos situaciją ir pokyčius matuoti patartina ne iš toli, o vietoje sukurtais ir ištestuotais instrumentais. Viena iš galimybių - jau septynis kartus išbandytas Lietuvos korupcijos žemèlapis.

- Trečia, pokyčiai visuomenès vertybių, nuostatų ir gero valdymo sferose yra lèti. Todèl norint ịvertinti antikorupcinių iniciatyvų veiksmingumą ir rezultatus reikia daugiau laiko. Korupcijos tyrimai dažnai rodo mažai kintančią situaciją.

- Ir ketvirta, kiek Lietuvoje yra ieškančių pažangos „kovoje“ su korupcija? Garsių sẻkmès istorijų, kaip pavyzdžiui Valstybinès mokesčiu inspekcijos, kuriai pavyko sumažinti kyšininkavimo indeksą, istorija 2006 metais, yra vienetai, o papasakotų nesèkmių istorijų - šimtai.

Vilnius, 2012 m. lapkritis - 2013 m. sausis

\footnotetext{
${ }^{63}$ Lietuvos pažangos strategijoje „Lietuva 2030“ keliami tikslai, kad Lietuva KSI tyrime užimtų ne žemesnę nei 10 vietą tarp ES šalių.
} 